\title{
Hypothalamic-Pituitary Axis Dysfunction and Metabolic Derangements in Thai Childhood Leukemia Survivors
}

\begin{abstract}
Aims: To determine the prevalence and severity of endocrine and metabolic derangements in childhood-onset ALL survivors from Thailand and to describe the associated risk factors. Settings and Design: Paediatric department in medical school hospital, cross-sectional study. Methods: Insulin Tolerance Test (ITT), IGF-I and IGFBP-3 levels, Thyroid and gonadal function, serum sodium and metabolic profiles were investigated in 30 childhood onset ALL survivors. (16 males, 14 females, mean age: $14.66 \pm 7.16$ years). Results: Endocrine abnormalities were displayed in 73.33 $\%$ of patients, $46.7 \%$ had two or more abnormalities. Grade 3 of severity were present in $16.67 \%$. Growth hormone deficiency (GHD) was detected in 10 patients $(33 \%)$. Early onset of ALL was the potential risk factor of GHD. Adult height was more deteriorated in the female group. Twenty percent of patients were found with subnormal cortisol responses. Gonadal failure was evidenced in one case that experienced testicular irradiation. No diabetes insipidus was detected. Among 6 obese patients, 2 patients developed metabolic syndrome. Moreover, one patient was diagnosed with insulin-depleted diabetes mellitus. Conclusion: Our results highlighted various endocrine and metabolic sequelae occurring in childhood-onset ALL survivors after completion of their therapy. The prevalence of GHD was higher than the one previously described in Japan population. Subclinical hormonal abnormalities may affect health outcomes. Biochemical and hormonal abnormalities should be carefully monitored for immediate treatment.
\end{abstract}

Keywords: Acute leukemia, endocrine, insulin tolerance test, survivors, Thailand

\section{Introduction}

The survival rate of acute lymphoblastic leukemia (ALL) in Thailand has improved significantly during the last decade. Notably, the 5-year overall survival of ALL in Thailand reached $67.2 \% .^{[1]}$ Approximately $90 \%$ of childhood cancer survivors develop medical complications or deficiencies. ${ }^{[2]}$ Endocrinopathies, including hypothalamicpituitary axis (HP axis) dysfunction and metabolic derangements, represent the most frequent long-term complications associated with leukemia treatment. These endocrine abnormalities are mainly characterized by growth hormone deficiency (GHD), precocious puberty, gonadal dysfunction, metabolic syndrome, and obesity. ${ }^{[3,4]}$

HP axis dysfunction is frequently observed in ALL survivors following chemotherapy and cranial radiotherapy (CRT). ${ }^{[5,6]}$ Growth patterns among ALL survivors commonly display height deficit and impairment of growth hormone $(\mathrm{GH})$ /insulin-like growth

This is an open access journal, and articles are distributed under the terms of the Creative Commons Attribution-NonCommercial-ShareAlike 4.0 License, which allows others to remix, tweak, and build upon the work non-commercially, as long as appropriate credit is given and the new creations are licensed under the identical terms.

For reprints contact: WKHLRPMedknow_reprints@wolterskluwer.com factor (IGF-I) axis, especially in young age patients with ALL diagnosis who were treated by CRT. $^{[7]}$ Central hypothyroidism was rarely observed in ALL survivors. Central adrenal insufficiency (CAI) could also occur by moderate-dose CRT (18-24 Gy). ${ }^{[8,9]}$ ALL survivors treated with CRT initiated their puberty significantly earlier than those who were not treated with CRT. ${ }^{[10]}$

Posterior pituitary complication such as central diabetes insipidus (central DI), was rarely observed in ALL survivors treated with standard dose-based CRT. ${ }^{[3,4]}$

Obesity and metabolic syndrome also affect a substantial proportion of ALL survivors with a prevalence of $30 \%-40 \%$. CRT and prolonged exposure to high-dose glucocorticoids represents significant risk factors for the development of these disorders. ${ }^{[11]}$

HP axis dysfunction and metabolic derangements remain poorly investigated in Asian population, especially in Southeast

\footnotetext{
How to cite this article: Bongsebandhu-phubhakdi C, Wacharasindhu S. Hypothalamic-pituitary axis dysfunction and metabolic derangements in Thai childhood leukemia survivors. Indian J Med Paediatr Oncol 2020;41:688-94.
}

\section{Chansuda Bongsebandhu- phubhakdi, Suttipong Wacharasindhu}

Department of Pediatrics, Faculty of Medicine, Chulalongkorn University and King Chulalongkorn Memorial Hospital, Bangkok, Thailand

Submitted: $28-N o v-2019$

Revised: 03-Apr-2020

Accepted: 19-Jun-2020

Published: 29-Oct-2020

Address for correspondence: Dr. Chansuda Bongsebandhuphubhakdi,

Department of Pediatrics,

Faculty of Medicine,

Chulalongkorn University and King Chulalongkorn Memorial Hospital, 1873 Rama 4 Rd., Pathumwan, Bangkok 10330, Thailand.

E-mail: chansuda.b@gmail.com, chansuda.b@chula.ac.th

Access this article online

Website: www.ijmpo.org

DOI: 10.4103/ijmpo.ijmpo_238_19

Quick Response Code:

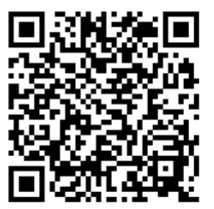


Asians. ${ }^{[12-15]}$ Pharmacoethnicity, which refers to ethnic variance in drug response and toxicities, may affect the long-term health outcomes, together with health behavior and lifestyle differences. ${ }^{[16]}$

The goal of the present study was to measure the prevalence and severity of hormonal abnormalities and metabolic disturbances in Thai childhood ALL survivors as well as to identify the associated risk factors for prevention or better control of subsequent complications.

\section{Materials and Methods}

\section{Selection and description of participants}

Forty ALL survivors, who were in complete remission for more than 1 year, were invited to participate in this study. Thirty patients completed the full study. ALL was diagnosed when subjects were $<15$ years old from 1990 to 2007. No patient treated with bone marrow transplantation was recruited into this study. Twenty-five patients $(83.33 \%)$ were in the first clinical remission whereas five patients were in their second remission after treatment for a recurrence. A review of all medical records was performed.

All of the patients were treated for 2-3 years by chemotherapy including traditional drugs used for induction, consolidation and maintenance phases (vincristine, L-asparaginase, methotrexate, prednisolone, 6-mercaptopurine, etc.) according to the Thai Pediatric Oncology Group protocol. ${ }^{[1]}$ Twenty-four patients $(80 \%)$ received central nervous system (CNS) prophylaxis through cranial 18 Gy radiation dose. Six patients were not submitted to prophylactic CRT because their ages were under 2-year-old at the time of diagnosis; however, one underwent CRT at a later point in time for the treatment of CNS relapse. Two of the 16 male patients had testicular irradiation (18 Gy) because of testicular relapse.

This study has been approved by the Ethics Committee of the Faculty of Medicine, Chulalongkorn University. (IRB approval number 18452).

\section{Methods}

All participants attended the outpatient unit from the specified time period of 7-8 a.m. Baseline data were collected. Due to the lack of standard sex and age matched childhood body mass index (BMI) curves for Thai children, we used the International Obesity Taskforce childhood BMI reference instead. ${ }^{[17]}$ Patients with a BMI of more than the $85^{\text {th }}$ percentile was classified as overweight; patients with a BMI of more than the $95^{\text {th }}$ percentile was classified as obese. Skeletal age was determined by pediatric endocrinologists using the Greulich and Pyle method. ${ }^{[18]}$ Predicted adult height (PAH) was calculated with the Bayley-Pinneau method. ${ }^{[19]}$ The Final adult height $(\mathrm{FAH})$ was considered achieved when annual increment was $<1 \mathrm{~cm}$, with bone age of over 15 years mid-parental height (MPH) following the formula: (father's height $[\mathrm{cm}]+$ mother's height $[\mathrm{cm}]$ +13 ) $/ 2$ for boys and (father's height $[\mathrm{cm}]+$ mother's height $[\mathrm{cm}]-13) / 2$ for girls. All height was adjusted into standard deviation (SD) and SD scores (SDS), based on the Thai National Survey of Health 1997. ${ }^{[20]}$

Serum samples were collected after overnight fasting for the measurement of IGF-I, IGF binding protein-3 (IGFBP-3), thyroid-stimulating hormone (TSH), free T3, free T4, luteinizing hormone (LH), follicle-stimulating hormone (FSH), estradiol (in female), testosterone (in male), serum sodium, fasting plasma glucose (FPG), insulin and lipid profiles (cholesterol, triglyceride [TG], high-density lipoprotein [HDL] and low-density lipoprotein).

To evaluate GH status, insulin tolerance test (ITT) was performed using blood samples collected at 0, 15, 30, 45, and $90 \mathrm{~min}$. GHD was considered if $\mathrm{GH}$ level was lower than $5 \mu \mathrm{g} / \mathrm{L}$ or $10 \mu \mathrm{g} / \mathrm{L}$ for patients who either attained or did not attain final height, respectively. ${ }^{[21]}$ The IGF-I and IGFBP-3 concentrations were measured by an automated chemiluminescent assay (IMMULITE®), Diagnostic Products Corp, Los Angeles, CA, USA). ${ }^{[22]}$ IGF-I and IGFBP-3 levels were categorized into age-related $-2,-1$, $0,+1,+2, \mathrm{SD}$ using reference ranges for normal population as reported by Elmlinger et al..$^{[23]}$

HP-adrenal (HPA) axis was also evaluated during ITT. The cortisol response was considered as normal based on achievement of a peak level of $18 \mu \mathrm{g} / \mathrm{dL}$ or above. Patients with peak cortisol level $<4 \mu \mathrm{g} / \mathrm{dL}$ and $18 \mu \mathrm{g} / \mathrm{dL}$ were classified in the cortisol deficiency group and subnormal cortisol response group, respectively. ${ }^{[2]}$

Hypothyroidism was considered when a patient had lower free T3 and free T4 than normal range and subclinical hypothyroidism was diagnosed when a patient displayed normal free $\mathrm{T} 3$, free $\mathrm{T} 4$ and $\mathrm{TSH}$ level above the limit (4.1 mU/L).

Hypogonadism was characterized by failure to initiate puberty at 13 and 14-year-old for female and male subjects, respectively or by a failure to progress through puberty after the occurrence of secondary sex characteristics.

DI was screened by episodes of polyuria and polydipsia as well as high serum sodium levels.

FPG and hemoglobin Alc were assayed for diabetes mellitus (DM). DM was defined according to American Diabetes Association criteria. ${ }^{[24]}$ Metabolic syndrome was defined following International Diabetes Federation clinical criteria (waist circumference $\geq 90^{\text {th }}$ percentile, $\mathrm{TG} \geq 150 \mathrm{mg} / \mathrm{dL}, \mathrm{HDL} \leq 40 \mathrm{mg} / \mathrm{dL}$ in male and $<50 \mathrm{mg} / \mathrm{dl}$ in female, systolic blood pressure $\geq 135$, diastolic blood pressure $\geq 85 \mathrm{mmHg}$ and FPG, FPG $\geq 100 \mathrm{mg} / \mathrm{dL}$.). ${ }^{[25]}$

The severity of specific late complication was graded based on the Common Terminology Criteria of Adverse Events version 5.0. ${ }^{[26]}$ The late effects were scored from 
Grades 1-5 with descriptions of severity for each adverse event (Grade 1, mild; 2, moderate; 3, severe; 4, life threatening or disabling; 5, death-related adverse event).

\section{Statistics}

Data were presented as mean $\pm \mathrm{SD}$ or as mean (range). Mean of MPH and FAH (or PAH) was compared and analyzed using Paired-Sample $t$-test. Pearson's and Spearman's correlation coefficients were used to assess relationships between normally and nonnormally distributed variables, respectively. $P<0.05$ was considered statistically significant. All computations were performed using the SPSS Statistics for Windows, Version 17.0. (SPSS Inc., Chicago, IL, USA).

\section{Results}

A total of 30 patients were recruited in this study, 16 male and 14 female survivors of childhood-onset ALL. Study participant baseline characteristics are shown in Table 1. The onset of leukemia appeared between the ages of 1.1 years and 14.1 years. Twenty-five patients $(83.33 \%)$ received CRT for CNS prophylaxis. None of the patients was diagnosed with endocrine deficiency or continued hormonal therapy before their participation in this study. Endocrine abnormalities were recently detected in 22 patients $(73.33 \%)$. Ten survivors $(33.33 \%)$ had Grade 1 (mild) and 7 (23.33\%) had Grade 2 (moderate) severity of late effects. Grade 3 was found in $16.67 \%$ of survivors.

Two patients (6.67\%), one male and one female, had FAH SDS (or PAH SDS) <-2SD. Eighteen of the 30 patients $(60 \%)$ were shorter than MPH. Subgroup analysis showed that females had a significant reduction of FAH (or PAH) (152.83 $\pm 5.47 \mathrm{~cm}$ ) compared to their MPH $(156.82 \pm 3.83)(P=0.009)$. The survivors' adult height was shown not to be correlated with CRT or age at diagnosis or years of follow up after completion of treatment. Two patients with short stature (shorter than -2SD) had psychological distress for growth disorders, requiring psychiatric consultation.

Growth hormone, insulin-like growth factor -I, and insulin-like growth factor binding protein-3 axis

GHD was diagnosed in patients $<18$ years old, with a prevalence reaching $45.5 \%$ (10/22 patients) [Figure 1]. The development of ALL in subjects with an age $<5$-year-old

Table 1: Characteristics of the patients, final adult height or predicted adult height standard deviation scores, severity of late effects

\begin{tabular}{|c|c|c|c|}
\hline & Total & Male & Female \\
\hline$n$ & 30 & 16 & 14 \\
\hline \multicolumn{4}{|l|}{ Age (years), $n(\%)$} \\
\hline$<18$ & $22(73.33)$ & $12(75)$ & $10(71.43)$ \\
\hline$>18$ & $8(26.67)$ & $4(25)$ & $4(28.57)$ \\
\hline Age at diagnosis, median (range) & $\begin{array}{l}5 \text { years ( } 1 \text { years } 1 \text { months- } 14 \\
\text { years } 1 \text { months) }\end{array}$ & $\begin{array}{l}5 \text { years } 4 \text { months }(1 \text { years } 8 \\
\text { months- } 14 \text { years } 1 \text { months })\end{array}$ & $\begin{array}{l}4 \text { years } 9 \text { months }(1 \text { years } 1 \\
\text { months- } 14 \text { years })\end{array}$ \\
\hline Age at assessment, median (range) & $\begin{array}{l}14 \text { years } 8 \text { months }(7 \text { years } 2 \\
\text { months- } 21 \text { years } 9 \text { months) }\end{array}$ & $\begin{array}{l}14 \text { years } 9 \text { months }(7 \text { years } 2 \\
\text { months- } 21 \text { years } 1 \text { months) }\end{array}$ & $\begin{array}{c}14 \text { years } 6 \text { months }(10 \text { years } 2 \\
\text { months- } 21 \text { years } 9 \text { months })\end{array}$ \\
\hline $\begin{array}{l}\text { Follow up after completion of } \\
\text { treatment, median (range) }\end{array}$ & $\begin{array}{c}6 \text { years } 2 \text { months ( } 1 \text { years- } 14 \\
\text { years } 3 \text { months) }\end{array}$ & $\begin{array}{c}5 \text { years } 6 \text { months ( } 1 \text { years- } 10 \\
\text { years } 7 \text { months) }\end{array}$ & $\begin{array}{l}6 \text { years } 9 \text { months }(1 \text { years } 9 \\
\text { months- } 14 \text { years } 3 \text { months })\end{array}$ \\
\hline CRT/non-CRT $(n)$ & $25 / 5$ & $14 / 2$ & $11 / 3$ \\
\hline $\mathrm{MPH}$, mean $\pm \mathrm{SD}(\mathrm{cm})$ & $163.78 \pm 8.15$ & $169.87 \pm 5.56$ & $156.82 \pm 3.83^{\pi}$ \\
\hline $\mathrm{MPH}$ SDS, mean \pm SD & $0.02 \pm 0.92$ & $0.0519 \pm 1.048$ & $-0.165 \pm 0.797^{\pi}$ \\
\hline $\mathrm{FAH}$ or $\mathrm{PAH}$, mean $\pm \mathrm{SD}(\mathrm{cm})$ & $161.82 \pm 10.67$ & $169.67 \pm 7.28$ & $152.83 \pm 5.47 *$ \\
\hline FAH or PAH SDS, mean \pm SD & $-0.388 \pm 1.32$ & $0.146 \pm 1.373$ & $-0.848 \pm 1.14^{* *}$ \\
\hline FAH SDS $<-2 \mathrm{SD}, n(\%)$ & $2(6.67)$ & $1(3.33)$ & $1(3.33)$ \\
\hline Existence of late effects, $n(\%)$ & $22(73.33)$ & $10(62.5)$ & $12(85.71)$ \\
\hline \multicolumn{4}{|l|}{ Number of late effects, $n(\%)$} \\
\hline 1 & $8(26.67)$ & $3(18.75)$ & $5(35.71)$ \\
\hline 2 & $9(30)$ & $6(37.5)$ & $3(21.43)$ \\
\hline 3 & $5(16.67)$ & $1(6.25)$ & $4(28.57)$ \\
\hline \multicolumn{4}{|l|}{$\begin{array}{l}\text { Severity of late effects per } \\
\text { survivors, } n(\%)\end{array}$} \\
\hline Grade 1 (mild) & $10(33.33)$ & $3(18.75)$ & $7(50)$ \\
\hline Grade 2 (moderate) & $7(23.33)$ & $3(18.75)$ & $4(28.58)$ \\
\hline Grade 3 (severe) & $5(16.67)$ & $4(25)$ & $1(7.14)$ \\
\hline
\end{tabular}

$* P<0.05$ versus $\uparrow, * * P<0.05$ versus ${ }^{\pi}$. FAH (or PAH) in female patients was significantly reduced compared to their MPH $(P=0.009)$. FAH - Final adult height; PAH SDS - Predicted adult height standard deviation scores; MPH - Midparental height; CRT - Cranial radiation therapy; SD - Standard deviation 


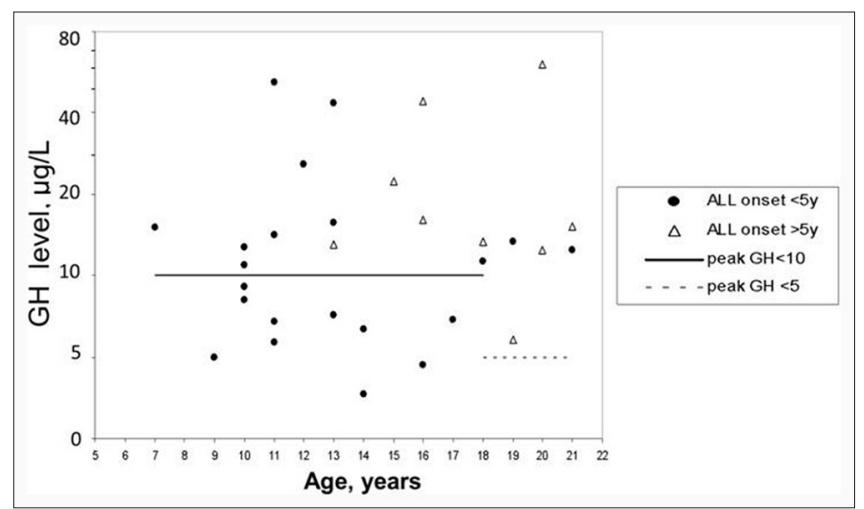

Figure 1: Peak of Growth hormone $(\mu \mathrm{g} / \mathrm{L})$ in ITT

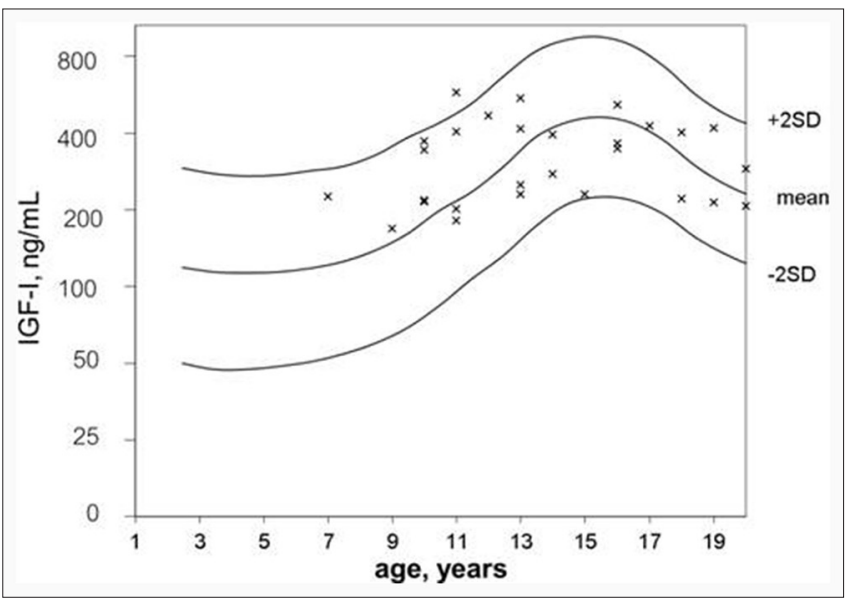

Figure 2: Insulin-like growth factor-I ( $\mathrm{ng} / \mathrm{mL})$ in age-matched reference curve

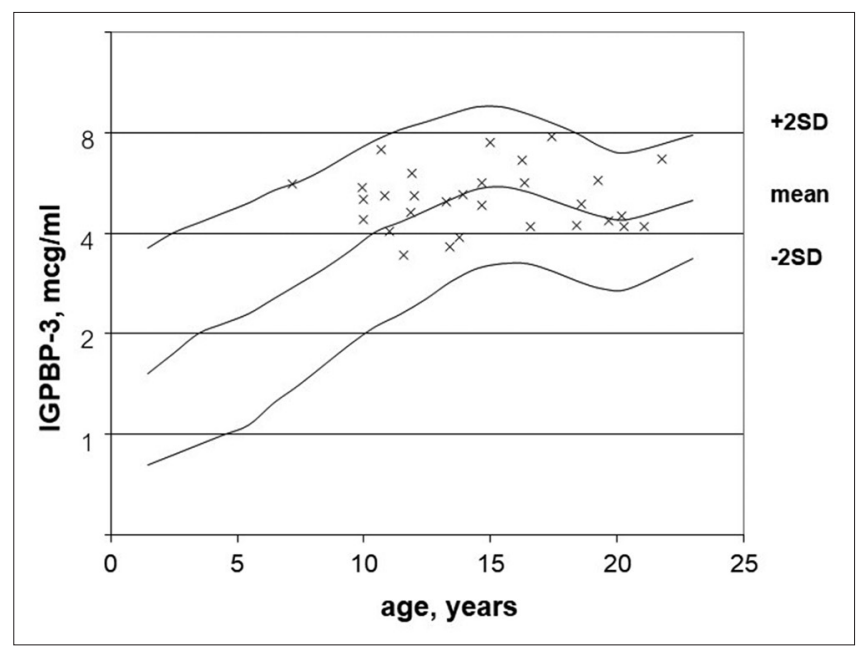

Figure 3: Insulin-like growth factor binding protein $3(\mathrm{mcg} / \mathrm{ml})$ in agematched reference curve

was statistically correlated with peak $\mathrm{GH}$ and GHD ( $P=0.0089,0.033$, respectively). CRT and dosage of CRT was not correlated with GH response.

As shown in Figures 2 and 3, IGF-I and IGFBP-3 levels reached the normal age-related reference range $(-2 \mathrm{SD}$ to $+2 \mathrm{SD})$ and the IGF-I $z$-score was strongly correlated to
IGFBP-3 $z$-score $(P=0.000581)$. Patients diagnosed with GHD displayed lower IGF-I $z$-score $(-0.50 \pm 0.972)$ and IGFBP-3 $z$-score $(-0.20 \pm 1.033)$ compared with subjects from the non-GHD group $(0.05 \pm 1.146,0.05 \pm 0.887$, respectively. FAH (or $\mathrm{PAH}$ ) SDS showed no statistical correlation with GHD, IGF-I $z$-score and IGFBP-3 $z$-score.

\section{Thyroid axis}

One female with infantile ALL was diagnosed with subclinical hypothyroidism but without evidence of goiter or family history of autoimmune thyroiditis. She did not receive CRT. The thyroid dysfunction of this subject was characterized by TSH, FT4 and FT3 serum concentrations of17.73 mU/L, FT4 $1.24 \mathrm{ng} / \mathrm{dL}$ and FT3 $3.34 \mathrm{pg} / \mathrm{mL}$, respectively. Antibodies to thyroglobulin and thyroperoxidase were not detected.

\section{Gonadal function}

Primary hypogonadism, low testosterone and high $\mathrm{LH}$, FSH, was evidenced in one male patient who experienced two courses of chemotherapy, testicular biopsy and testicular irradiation due to testicular relapse. This subject did not show any signs of puberty at 14.8 years old.

Central precocious puberty was found in 2 of 14 female patients, both of whom underwent low dose CRT. Spontaneous puberty and menarche were observed in other female patients appropriately with their Tanner pubertal staging.

\section{Hypothalamic-pituitary-adrenal axis}

Six out of 30 subjects $(20 \%)$ developed subnormal cortisol response (cortisol peak $<18 \mu \mathrm{g} / \mathrm{dL}$ ) in ITT. No correlation was found between cortisol peak and the onset age of ALL, range of follow-up years after treatment completion or CRT. None of the patients displayed impaired HPA axis (cortisol peak $\leq 4 \mu \mathrm{g} / \mathrm{dL}$ ).

\section{Diabetes insipidus}

None of the participants had a history of polyuria, polydipsia or had hypernatremia suggestive of DI.

\section{Obesity and metabolic disturbances}

One female and three males out of 30 patients $(16.67 \%)$ were considered obese whereas one female and one male were overweight. All of them underwent CRT for CNS prophylaxis.

One out of 30 patients was recently diagnosed with DM. He had a normal BMI together with mild symptoms of polyuria and polydipsia. The patient's blood test showed no evidence of hyperinsulinism according to the levels of fasting insulin.

Five out of 30 patients $(16.66 \%)$ had hypertriglyceridemia (TG $\geq 150 \mathrm{mg} / \mathrm{dL}$ ) while 10 out of 30 patients $(33.33 \%$ ) had reduced HDL. No patient in the study group developed systolic or diastolic hypertension [Table 2]. Two out 


\begin{tabular}{|c|c|c|c|}
\hline \multicolumn{4}{|c|}{ Table 2: Metabolic profiles } \\
\hline & Total & Male & Female \\
\hline$n$ & 30 & 16 & 14 \\
\hline $\mathrm{BMI}$, mean $\pm \mathrm{SD}$ & $21.31 \pm 6.65$ & $21.69 \pm 7.19$ & $20.85 \pm 6.14$ \\
\hline Normal BMI, $n(\%)$ & $25(83.33)$ & $13(81.25)$ & $12(85.71)$ \\
\hline Overweight, $n(\%)$ & $1(3.33)$ & $0(0)$ & $1(7.14)$ \\
\hline Obesity, $n(\%)$ & $4(13.33)$ & $3(18.75)$ & $1(7.14)$ \\
\hline Fasting plasma glucose $(\mathrm{mg} / \mathrm{dL})$, mean $\pm \mathrm{SD}$ & $83.9 \pm 17.70$ & $86.75 \pm 22.29$ & $80.64 \pm 5.63$ \\
\hline Fasting insulin $(\mu \mathrm{U} / \mathrm{mL})$, mean $\pm \mathrm{SD}$ & $9.29 \pm 5.95$ & $9.55 \pm 6.72$ & $9.01 \pm 6.34$ \\
\hline $\mathrm{HbA} 1 \mathrm{C}(\mathrm{mg} \%)$, mean $\pm \mathrm{SD}$ & $5.63 \pm 0.39$ & $5.74 \pm 0.44$ & $5.51 \pm 0.39$ \\
\hline HOMA-IR, mean \pm SD & $1.95 \pm 1.30$ & $2.04 \pm 1.40$ & $1.85 \pm 1.31$ \\
\hline Fasting TG $(\mathrm{mg} / \mathrm{dL})$, mean $\pm \mathrm{SD}$ & $101.26 \pm 48.89$ & $101.38 \pm 51.53$ & $101.14 \pm 51.89$ \\
\hline $\mathrm{HDL}(\mathrm{mg} / \mathrm{dL})$, mean $\pm \mathrm{SD}$ & $57.43 \pm 16.99$ & $54.43 \pm 11.83$ & $60.85 \pm 11.88$ \\
\hline Metabolic syndrome, $n(\%)$ & $1 / 30(3.33)$ & $1 / 16(6.25)$ & $0 / 14(0)$ \\
\hline $\mathrm{DM}, n(\%)$ & $1 / 30(3.33)$ & $1 / 16(6.25)$ & $0 / 14(0)$ \\
\hline
\end{tabular}

BMI - Body mass index; Hb1AC - Hemoglobin A1c; HOMA-IR - Homeostatic Model Assessment of Insulin Resistance; Fasting TG Fasting Triglycerides; HDL - High-density lipoprotein; DM - Diabetes mellitus; SD - Standard deviation

of 30 patients $(6.67 \%)$ were diagnosed with metabolic syndrome due to high TG and low HDL.

\section{Discussion}

With an average follow-up of 6 years, this study revealed that $73.33 \%$ of Thai leukemia survivors showed endocrine and metabolic derangement. The point prevalence was $33.33 \%$ for GHD, 20\% for subnormal cortisol responses, $3.33 \%$ for subclinical hypothyroidism, 33.33\% reduced HDL and $16.67 \%$ for obesity.

GHD was demonstrated in one-third of the patients and this prevalence was much higher than the one previously reported in Japan $(2.8 \%),{ }^{[12]}$ but lower than the frequency measured in a large US cohort (46.5\%). ${ }^{[27]}$ This might be caused by the different method of $\mathrm{GH}$ assessment and also could be due to fewer subjects in our study. Nevertheless, the IGF-I and IGF-BP3 serum concentrations in our GHD cases were low to normal and height SDS was not compromised significantly. These data suggest that ALL treatment marginally reduced pituitary function at the level of $\mathrm{GH}$ production and/or secretion. Survivors with ALL onset appearing in the first 5 years of life were at risk of GHD, as described previously. ${ }^{[27]}$ Therefore, continuous screening and subsequent treatment for GHD disorder should be implemented. Untreated GHD is commonly associated with abdominal obesity, low muscle mass, low energy expenditure, muscle weakness, and poor exercise tolerance over the following years. ${ }^{[28]}$

A previous study in Thailand ${ }^{[29]}$ demonstrated that girls completing their ALL treatment had less adult height deficit than boys, resulting from more consistent weight gain. Conversely, in our population, we found remarkable decrease in height of female patients, which could be explained by the phenomenon of early onset puberty which is more commonly observed in female than male patients.

Abnormal thyroid function due to primary and secondary hypothyroidism has been reported after high dose CRT and even during a long period of time after treatment completion. ${ }^{[30]}$ In our study, most patients received CRT at a lower dose (18 Gy) and only two received higher doses (36 and 39 Gy). However, all of them had normal thyroid function test results during our 4 year-10 month follow-up. Nevertheless, it would be interesting to screen this thyroid disorder over a longer period as central hypothyroidism could arise at any time following treatment. $^{[31]}$ One female with subclinical hypothyroidism of unknown origin had been treated with CRT and did not develop thyroid-specific autoantibodies. The etiology of her subclinical hypothyroidism is inconclusive.

Reproductive abnormalities could result from direct damage of the gonads by systemic chemotherapy, alteration of the HP -gonad axis and cancerous cell infiltration in the gonad. ${ }^{[2]}$ One out of 16 male patients suffered from gonadal failure due to testicular relapse, a direct effect of testicular irradiation and repeated course of chemotherapy. Consequently, long-term reproductive analysis including sperm cell counting and fertility rate should be monitored in all male survivors. In female patients, 2 of 14 patients $(14.28 \%)$ were diagnosed with precocious puberty. This abnormality can be associated with low-dose CRT. ${ }^{[32]}$ None of the female patients from our study were reported with delayed puberty or primary amenorrhea. Nevertheless, we cannot exclude the development of other late effects such as pregnancy rate and premature menopause during a longer follow-up.

In this study, 6 subnormal cortisol responses $(20 \%$ of all patients) were detected. Five of these 6 subjects were female. Although female gender seems to have poorer cortisol increment in testing, this observation remains to be explained and should be further investigated. ${ }^{[8,33]}$ Clinical signs and symptoms of adrenal insufficiency as well as a record of adrenal crisis were not evidenced in subjects with subnormal cortical response. However, glucocorticoid supplementation during major stress is considered to prevent consequences of adrenal crisis. 
In agreement with previously reported studies, none of the participants suffered from DI. ${ }^{[34,35]}$ It must be pointed out that, in ALL survivors, DI does not usually result from hypothalamic and pituitary tumors because standard ALL treatment protocols are commonly based on cranial irradiation.

Some evidences suggest that cancer survivors in general and particularly survivors of childhood ALL are highly susceptible to develop metabolic syndrome. ${ }^{[15]}$ Metabolic syndrome is a significant risk factor for further cardiovascular disease and $\mathrm{DM}^{\left[{ }^{[36]}\right.}$ Our present data highlighted that reduced HDL $(33.33 \%)$ is the most common of metabolic disturbance which could represent the first emerging metabolic complication in childhood ALL survivors.

One patient of our cohort, without family history of DM but having mild symptoms of diabetes and no signs of insulin resistance, was newly diagnosed with DM. The measured insulin level (5.6 $\mathrm{mU} / \mathrm{L})$ and the absence of anti-GAD autoantibodies suggested that the etiology of DM for this patient resulted from pancreatic $\beta$-cell deterioration. ${ }^{[37]}$

\section{Conclusion}

The present study described the higher prevalence of subclinical abnormalities of metabolic and hormonal profiles than previously reported findings among Asian population. These disorders will negatively influence the health and quality of life of ALL survivors in the future. A systematic and periodic monitoring of growth parameters, $\mathrm{GH}$ axis, adrenal function and obesity is consequently recommended for all childhood-onset ALL survivors.

\section{Acknowledgments}

This research was supported by Chula Quality Improvement Fund, King Chulalongkorn Memorial Hospital, The Thai Red Cross society.

\section{Financial support and sponsorship}

Nil.

\section{Conflicts of interest}

There are no conflicts of interest.

\section{References}

1. Seksarn P, Wiangnon S, Veerakul G, Chotsampancharoen T, Kanjanapongkul S, Chainansamit SO. Outcome of childhood acute lymphoblastic leukemia treated using the Thai national protocols. Asian Pac J Cancer Prev 2015;16:4609-14.

2. Rose SR, Horne VE, Howell J, Lawson SA, Rutter MM, Trotman GE, et al. Late endocrine effects of childhood cancer. Nat Rev Endocrinol 2016;12:319-36.

3. Chemaitilly W, Cohen LE. Diagnosis of endocrine disease: Endocrine late-effects of childhood cancer and its treatments. Eur J Endocrinol 2017;176:R183-203.

4. Ward E, DeSantis C, Robbins A, Kohler B, Jemal A. Childhood and adolescent cancer statistics, 2014. CA Cancer J Clin 2014;64:83-103.
5. Rose SR, Schreiber RE, Kearney NS, Lustig RH, Danish RK, Burghen GA, et al. Hypothalamic dysfunction after chemotherapy. J Pediatr Endocrinol Metab 2004;17:55-66.

6. Gurney JG, Ness KK, Sibley SD, O'Leary M, Dengel DR, Lee JM, et al. Metabolic syndrome and growth hormone deficiency in adult survivors of childhood acute lymphoblastic leukemia. Cancer 2006;107:1303-12.

7. Vilela MI, Serravite Mde O, Oliveira NB, de Brito PC, Ribeiro-Oliveira A Jr, Viana MB. Height deficit and impairment of the GH/IGF-1 axis in patients treated for acute lymphoblastic leukemia during childhood. Horm Res Paediatr 2013;79:9-16.

8. Follin C, Wiebe T, Moëll C, Erfurth EM. Moderate dose cranial radiotherapy causes central adrenal insufficiency in long-term survivors of childhood leukaemia. Pituitary 2014;17:7-12.

9. Gordijn MS, van Litsenburg RR, Gemke RJ, Bierings MB, Hoogerbrugge PM, van de Ven PM, et al. Hypothalamic-pituitary-adrenal axis function in survivors of childhood acute lymphoblastic leukemia and healthy controls. Psychoneuroendocrinology 2012;37:1448-56.

10. Elitzur S, Houri-Shtrecher R, Yackobovitz-Gavan M, Avrahami G, Barzilai S, Gilad G, et al. Growth and pubertal patterns in young survivors of childhood acute lymphoblastic leukemia. J Pediatr Endocrinol Metab 2017;30:869-77.

11. Zhang FF, Rodday AM, Kelly MJ, Must A, MacPherson C, Roberts SB, et al. Predictors of being overweight or obese in survivors of pediatric acute lymphoblastic leukemia (ALL). Pediatr Blood Cancer 2014;61:1263-9.

12. Hata M, Ogino I, Aida N, Saito K, Omura M, Kigasawa H, et al. Prophylactic cranial irradiation of acute lymphoblastic leukemia in childhood: Outcomes of late effects on pituitary function and growth in long-term survivors. Int J Cancer 2001;96 Suppl: 117-24.

13. Han JW, Kwon SY, Won SC, Shin YJ, Ko JH, Lyu CJ. Comprehensive clinical follow-up of late effects in childhood cancer survivors shows the need for early and well-timed intervention. Ann Oncol 2009;20:1170-7.

14. Han JW, Kim HS, Kim BS, Kwon SY, Shin YJ, Kim SH, et al. Increasing and worsening late effects in childhood cancer survivors during follow-up. J Korean Med Sci 2013;28:755-62.

15. Zareifar S, Haghpanah S, Shorafa E, Shakibazad N, Karamizadeh Z. Evaluation of metabolic syndrome and related factors in children affected by acute lymphoblastic leukemia. Indian J Med Paediatr Oncol 2017;38:97-102.

16. Ting Cheung Y. Cancer pharmacoethnicity: Ascertaining chronic health outcomes in survivors of childhood cancer in Asia. Glob J Pharmaceu Sci 2017;4:555634.

17. Cole TJ, Bellizzi MC, Flegal KM, Dietz WH. Establishing a standard definition for child overweight and obesity worldwide: International survey. BMJ 2000;320:1240-3.

18. Greulich WW, Pyle SI, Todd TW. Radiographic Atlas of Skeletal Development of the Hand and Wrist. California: Stanford University Press; 1950.

19. Bayley N, Pinneau SR. Tables for predicting adult height from skeletal age: Revised for use with the Greulich-Pyle hand standards. J Pediatr 1952;40:423-41.

20. National Health Foundation. Report of National Health Survey by Physical Measurement, phase II. Thailand: Ministry of Public Health; 1997.

21. Clayton PE, Cuneo RC, Juul A, Monson JP, Shalet SM, Tauber $\mathrm{M}$, et al. Consensus statement on the management of the GH-treated adolescent in the transition to adult care. Eur J Endocrinol 2005; 152:165-70.

22. Babson AL, Olson DR, Palmieri T, Ross AF, Becker DM, 
Mulqueen PJ. The IMMULITE assay tube: A new approach to heterogeneous ligand assay. Clin Chem 1991;37:1521-2.

23. Elmlinger MW, Kühnel W, Weber MM, Ranke MB. Reference ranges for two automated chemiluminescent assays for serum insulin-like growth factor I (IGF-I) and IGF-binding protein 3 (IGFBP-3). Clin Chem Lab Med 2004;42:654-64.

24. American Diabetes A. Diagnosis and classification of diabetes mellitus. Diabetes Care 2011;34 Suppl 1:S62-9.

25. Zimmet P, Alberti KG, Kaufman F, Tajima N, Silink M, Arslanian $\mathrm{S}$, et al. The metabolic syndrome in children and adolescents An IDF consensus report. Pediatr Diabetes 2007;8:299-306.

26. U.S. Department of Health and Human Services: National Institutes of Health and National Cancer Institute. Common Terminology Criteria for Adverse Events (CTCAE) Version 5.0; 2017. Available from: https://ctep.cancer.gov/ protocolDevelopment/electronic_applications/ctc.htm\#ctc_50. [last accessed on 2019 Jun 03].

27. Chemaitilly W, Li Z, Huang S, Ness KK, Clark KL, Green DM, et al. Anterior hypopituitarism in adult survivors of childhood cancers treated with cranial radiotherapy: A report from the St Jude Lifetime Cohort study. J Clin Oncol 2015;33:492-500.

28. Ness KK, Baker KS, Dengel DR, Youngren N, Sibley S, Mertens AC, et al. Body composition, muscle strength deficits and mobility limitations in adult survivors of childhood acute lymphoblastic leukemia. Pediatr Blood Cancer 2007;49:975-81.

29. Jaruratanasirikul S, Owasith K, Wongchanchailert M, Laosombat V, Sriplung $\mathrm{H}$. Growth patterns and final height of survivors of childhood leukemia. J Pediatr Endocrinol Metab 2004;17:719-26.

30. Lando A, Holm $\mathrm{K}$, Nysom $\mathrm{K}$, Rasmussen AK, Feldt-Rasmussen $\mathrm{U}$, Petersen $\mathrm{JH}$, et al. Thyroid function in survivors of childhood acute lymphoblastic leukaemia: The significance of prophylactic cranial irradiation. Clin Endocrinol (Oxf) 2001;55:21-5.

31. Baronio F, Battisti L, Radetti G. Central hypothyroidism following chemotherapy for acute lymphoblastic leukemia. J Pediatr Endocrinol Metab 2011;24:903-6.

32. Rutter MM, Rose SR. Long-term endocrine sequelae of childhood cancer. Curr Opin Pediatr 2007;19:480-7.

33. Darzy KH, Shalet SM. Absence of adrenocorticotropin (ACTH) neurosecretory dysfunction but increased cortisol concentrations and production rates in ACTH-replete adult cancer survivors after cranial irradiation for nonpituitary brain tumors. J Clin Endocrinol Metab 2005;90:5217-25.

34. Borson-Chazot F, Brue T. Pituitary deficiency after brain radiation therapy. Ann Endocrinol (Paris) 2006;67:303-9.

35. Gleeson HK, Shalet SM. The impact of cancer therapy on the endocrine system in survivors of childhood brain tumours. Endocr Relat Cancer 2004;11:589-602.

36. Meacham LR, Gurney JG, Mertens AC, Ness KK, Sklar CA, Robison LL, et al. Body mass index in long-term adult survivors of childhood cancer: A report of the Childhood Cancer Survivor Study. Cancer 2005;103:1730-9.

37. Earl M. Incidence and management of asparaginase-associated adverse events in patients with acute lymphoblastic leukemia. Clin Adv Hematol Oncol 2009;7:600-6. 